\title{
STRATEGIC PLANNING IN INCREASING QUALITY OF EDUCATION
}

\author{
Pebriana Priyambodo ${ }^{1)}$, Enung Hasanah ${ }^{2)}$ \\ 1), 2) Master of Education Management, Universitas Ahmad Dahlan, Yogyakarta, Indonesia \\ E-mail: ${ }^{1)}$ pebrianapriyambodo169@gmail.com ${ }^{2}$ enung.hasanah@mp.uad.ac.id
}

\begin{abstract}
This research is motivated by the low quality of education in Indonesia, especially primary education. Improving the quality of education is a must to meet the needs of schools and communities. One of the efforts made to make schools an active forum in improving the quality of education is strategic planning. This study aims to explore school strategic planning, analyze, and plan strategic planning in improving the quality of education at SDN Jetis Bantul. Researchers used descriptive research with a qualitative approach. Data collection techniques in this study were in-depth interviews, participant observation and documentation. This study's subjects were the principal, members of the principal's work deliberation, supervisors, teachers, and the school committee. Data analysis techniques used are data, data reduction, data presentation, drawing conclusions and levers. The results show that: (1) strategic planning is carried out by making an annual work plan following the vision, mission and goals of the school formulated at the beginning of the school year, forming a school development team, implementing school planning by educational procedures, developing development and coaching results achieving goals. (2) implementing school management strategies to diagnose systematically, plan, design and compile documents, establish policies, motivate educators and education personnel, allocate human resources, and develop a supportive strategic culture. (3) The evaluation of the school management strategy is carried out by analyzing its suitability with the strategic plan; the evaluation results used to assess a program, improvements, or colours. Supporting strategic planning factors are excellent support from students, teachers, supervisors, committees, student guardians and the school environment. The obstacle encountered in school strategic planning is the problem of the improper formulation. The school collaborates with the school committee and student guardians to solve these inhibiting factors to overcome this.
\end{abstract}

Keywords: Strategic Planning, Management, School Quality. 


\section{INTRODUCTION}

Education has a very important role in the development of human life as an individual and as a nation. Since the inception of the Unitary State of the Republic of Indonesia, the nation's educators have prioritized improving the quality of education as emphasized in the preamble to the 1945 Constitution that one of the goals of the Indonesian nation is to educate the nation's life. This is confirmed in the Law on National Education System No. 20 of 2003 which states that education is a conscious and planned effort to create a conducive atmosphere and learning process so that students actively develop their potential to have spiritual strength, self-control, personality, intelligence, noble character, and skills needed by themselves, society., nation and state.

The Indonesian Ministry of Education has made various efforts to improve the quality of education, including through curriculum development, increasing teacher competence, procurement of books, procurement of educational facilities and infrastructure and improvement in education management but the results have not been satisfactory (Depdiknas, 2005), but the quality of education in Indonesia is still low, especially in basic education (Suryana, 2011) In 2015, the quality of education in Indonesia is still at 128 out of 134 countries (Godwin, 2017), Indonesia's HDI ranks 107 out of 189 countries with an average length of study of 13 years (UNDP, 2020).

One of the factors that causes the low quality of education in Indonesia is that the school's ability to fully implement school strategic planning is still very minimal (Depdiknas, 2005). Schools as educational institutions have not been able to bridge parents and government in improving the quality of human resources and become active places in improving the quality of human resources through strategic planning (Triton, 2010). Therefore, schools need to improve their ability to carry out and control strategic management in order to achieve school goals and improve the quality of education (Rusmini, 2013).

Research on strategic planning has been done a lot. (Amirin, 2005) xamines strategic planning models in improving the quality of education. Through this research it can be concluded that strategic planning can produce strategic concepts that emphasize more on improving the quality of graduates and the quality of educators and educational personnel. The same thing was also expressed by (Kurniawati, 2017) who examined the strategic management of Islamic education institutions in improving the quality of education. The research resulted in the findings that the formulation of strategic planning in the external and internal environment could improve the quality of education. Not much different, the results of research conducted by Prasojo (2011) require careful strategic planning in change and joint decision-making can systematically affect the level of education quality. The same thing has been studied by Hefniy and Fairus (2019) 
the process of the stages of strategic planning, strategic implementation, and strategic evaluation is fairly good which is proven by referring to the fulfillment of the five main dimensions of education quality.

A review of four recent studies shows that strategic planning can improve the quality of education at the school level. Strategic planning to improve the quality of education in primary schools has not been carried out in full, the purpose of primary school education is to lay the foundation for intelligence, knowledge, personality, noble character, and independent living skills and follow further education, so students can have and instill a character attitude others (Law Number 20 of 2003). Therefore, strategic planning in improving the quality of education in elementary schools is very important to be studied and developed.

Based on the results of pre-research observations, it was found that the Jetis Public Elementary School, Bantul was the favorite educational institution in the Jetis district. Strategic planning in school development and management has increased every year. Since its establishment in 1984, it is still of high quality. This can be seen from the increase in community interest, the addition of school buildings, and various school achievements that have been achieved.

In 1995-1997, the Jetis State Elementary School had 414 students as well as facilities and infrastructure in the form of a prayer room, BK room and library. Furthermore, in 1998-1999, there was an increase in the number of educators and education personnel, namely 22 teachers and 3 education personnel. Every new academic year there was an increase in students, so that in 2000-2003 there was an increase in facilities and infrastructure, namely 18 classrooms, UKS rooms, computer laboratories and science laboratories. In 2004-2007 there was an increase in the number of students to 483 students. Then in 2008 the Jetis Public Elementary School created a superior class program for students with superior achievements. So that starting from 2010-2011, Jetis Public Elementary School has 21 classrooms, 3 superior classes and 18 regular classes. Furthermore, in 2012 the Jetis Public Elementary School was selected as a school that represents a partner in the DBE (Decentralized Basic Education) program in Jetis sub-district. This activity aims to increase access to quality education. In 2013 until now, Jetis Public Elementary School has achieved many achievements both academically and nonacademically. As well as getting accredited A continuously. Jetis Public Elementary School is one of the educational institutions that continues to strive to improve the quality of education.

Based on information from the principal, the quality of schools in the last three years after implementing strategic planning has improved. This can be seen from the achievements of the school in the last three years starting at the sub-district, district, and even provincial levels. The number of students 
has also increased in the last three years. Grade 6 school examination results also always rank first in Jetis sub-district.

The success achieved by SD Negeri Jetis in carrying out strategic planning in improving the quality of education can be a reference for school principals and other education practitioners to be able to carry out strategic planning in their respective schools. Therefore, we conducted a study aimed at exploring strategic management in an effort to develop the quality of education in SD Negeri Jetis. The theoretical contribution of this research is expected to enrich alternative theories of strategic planning in elementary schools. The questions in this research are: 1) How is strategic planning in improving the quality of education? 3) How is the implementation of strategic management in improving the quality of education? 4) How is the evaluation of strategic management in improving the quality of education?

\section{LITERATURE REVIEW}

\section{Strategic Planning}

(Lubis, 2008) explains that strategic planning is the process of deciding which programs the organization will undertake and the amount of resources to be allocated, so that future prospects can be enlarged and the risks to be achieved can be minimized. Kerzner (2001) defines strategic planning as a management tool for managing current conditions in making future projections, so that strategic plans are used as guidelines for organizations to use from their current conditions to work towards the next 5 to 10 years.

Nanang (2004: 56) emphasizes that strategic planning is part of the process of determining the main objectives, policies that regulate the procurement and utilization of strategic resources used to achieve objectives.

Based on the above opinion, it can be concluded that strategic planning is the process of deciding which programs the organization will undertake, by identifying what should be and what can be done. A guide for the organization from the conditions at hand to the conditions for the next few years in order to achieve the desired goals.

The planning concept is often referred to as decision making and management (Mintzberg: 1994). Boseman and Phatak (1989) explain that the strategic planning process includes seven interrelated parts, namely: (1) Assessment of the organization, in terms of strengths, weaknesses, opportunities and challenges (strengths, weaknesses, opportunities, and threats abbreviated as SWOT); (2) Formulation of the organizational mission; (3) Formulation of organizational philosophy and policies; (4) Establishing strategic objectives; (5) Organizational strategic determination; (6) Organizational strategic implementation; (7) Organizational strategic control. R.G. Murdick (1985) suggests eight steps in the preparation of a strategic plan including: (1) Analysis of current and future conditions; (2) Identification of the strengths and weaknesses of the institution/organization; 
(3) Consider norms; (4) Identification of possibilities and risks; (5) Determining the scope of results and community needs; (6) Assessing the supporting factors; (7) Formulating goals and criteria for success; (8) Determining the distribution arrangement and sources.

The conclusion from the above description is that strategic planning includes an assessment of the organization in terms of strengths, weaknesses, opportunities and challenges, formulating a mission and policy philosophy, setting strategic goals and implementing control. The step of compiling strategic planning requires analysis of current and future conditions, identifying strengths, weaknesses of the possibilities and risks of institutions/organizations, considering norms and determining the scope of needs and values of supporting factors, formulating objectives of success criteria, and determining distribution and resource arrangements. If these steps can be taken correctly, the strategic planning designed by the school will meet the desired results.

\section{Quality of Education}

Quality is the most important discussion topic in education at this time (Arcaro, 1995: 56). Quality is a degree of excellence in education management to produce academic and extracurricular excellence in students. Components related to the quality of education include: (1) student readiness and motivation; (2) The ability of professional teachers and cooperation in organizations; (3) curriculum, (content relevance and operational learning process); (4) Facilities and infrastructure (adequacy and effectiveness) (Sutikno, 2013: 92). Hoy and Miskel (2001: 308) state that quality can be interpreted as the level of a product or service that exceeds client expectations. In the context of education, quality includes the input, process, output and outcome of education (Depdiknas: 2002: 21).

Quality education produces graduates who have competency abilities, both academic and vocational, based on personal, social, and moral competences, all of which are life skills (Sudradjad, 2005: 17). Usman (2006: 410) states that the quality of education includes inputs, processes, outputs and outcomes. Educational input is declared of high quality if it is ready to proceed. Quality education process if it is able to create a gripping atmosphere. The output is stated to be of good quality if the student's academic and non-academic learning outcomes are high. Outcome is considered high quality if graduates are quickly absorbed in the world of work. Komariah (2005: 69) states that the characteristics of quality management are supported by several indicators, namely: (1) institutional management (calm and curriculum); (2) Learning services; (3) Student competencies obtained during the learning. Arrowsmith (1985: 46) states that the curriculum designed and developed by teachers is an effort to prepare students to have high quality intellectual, emotional, spiritual and social abilities. Learning services are very 
important in school organizations, learning is declared of quality if it is able to give birth to academic and extracurricular excellence in students (Danim, 2006: 245).

Based on these various opinions it can be concluded that improving the quality of education as an effort to change education cannot stand alone, but must involve all elements involved in it, such as school principals, teachers and students. In addition, the success of education quality includes indicators that can be used as benchmarks, namely curriculum, administration, organization, facilities and infrastructure, human resources, budget/financing, students, community participation and the environment.

\section{Strategic Planning to Improve Education Quality}

The planning of an educational institution has an important role. Through careful planning, schools will be able to produce appropriate strategies as an effort to achieve goals, the essence of planning as a strategic management process is decision making by sorting and selecting alternative activities to be carried out so that they are effective and efficient (Nawawi, 2005). Quality is an important part of the institution and must be approached systematically by the strategic planning process of total quality management, without clear long-term direction, an institution cannot plan for quality improvement (Sallis, 2012: 226).

The strategic planning process in improving the quality of education includes all activities, does not recognize standard standards and the process has variations. Each application needs to design variations according to needs, situations and conditions. The strategic planning process contains the following elements: (1) The formulation of a vision and mission; (2) external environmental assessment; (3) Internal environmental assessment; (4) Formulation of strategic issues; (5) Formulation of strategic development with goals and objectives (Djunaedi, 2000).

Based on the description above, it can be concluded that the strategic planning objectives are formulated to provide guidance and direction to the institution. The strategic planning process through the formulation of a vision and mission, external and internal environmental assessments, formulation of strategic issues, and strategic development with goals and objectives can help improve the quality of school education.

\section{METHODS}

This research uses descriptive research with a qualitative approach. The research was conducted at Jetis State Elementary School, Bantul. Sugiyono (2016) explains that the research subject is a person who usually provides information about the situation and conditions of the research place. The subjects of this study were the principal, the head of the principal's work meeting, supervisors, teachers, and the committee. The data continues to be explored by researchers until the data is at a saturated level. To obtain saturated data is not limited to the number of people, because 
qualitative research data will stop being extracted if it has triangulation data. The object of this research is data related to school strategic planning in improving the quality of education at Jetis Public Elementary School, Bantul.

\section{The data collection technique is} based on Sugiyono (2016) with participant observation, in-depth interviews, and documentation. Participant observation is a participatory technique in obtaining data by observing and listening as carefully as possible to what people do, listening to what they say and participating in activities (Satori, Djam'an and Komariah, 2010). According to Susan Stainback in Sugiyono (2016) states that interviews are provided for a means of gaining a deeper understanding of how researchers interpret a situation or phenomenon than can be obtained through mere observation. Documentation is a complement to the use of observation and interview methods in qualitative research (Sugiyono, 2016), documentation can be in the form of records of past events in the form of archives, writings, pictures or monumental works.

The data validity technique used by researchers was triangulation. Researchers used two triangulations, namely sources and techniques. According to Sugiyono (2016) source triangulation is getting data from different sources with the same technique. Triangulation technique is a different data collection technique to get data from the same source. Researchers used participant observation, interviews, and documentation from the same source.

The data analysis technique used includes four stages, namely; data collection, data reduction, data presentation, and drawing conclusions (Huberman, A. Michael and Miles, 1992) In detail, the test stages include; (1) Data Collection. Data collection was carried out through observation, interviews, and documentation. After the data collected is presented with a description of the results of the observations, transcripts of interviews and descriptions of the results of the research documentation; (2) Data Reduction. Data reduction is the process of selecting data that has been collected based on field data. Data from interviews were grouped according to interview questions. After concluding the outline of the interview results then grouped with the results of observation and documentation study, then a common thread is taken and then summarized based on the research questions; (3) Presentation of Data. Data is presented in a narrative format according to the research problem formulation. Presentation of research results accompanied by field evidence from interviews, observation and documentation. From the research results, the researcher then compared the theory; (4) Draw conclusions. The final result of data analysis is in the form of conclusions for school strategic planning. 


\section{RESULTS AND DISCUSSION}

\section{School Quality Strategic Planning}

The results of the interview with Ms. SW as the Principal of SD Negeri Jetis about the school's strategic planning through outreach activities are as follows:

“...The strategic arrangement in this school starts from developing a vision and mission statement, conducting external and internal audits, setting long-term goals, then formulating, evaluating, choosing strategic, and implementing. The vision statement is the first stage in strategic planning. The vision statement is often a single sentence to answer "what do we want to be?" "What will we achieve from this school?". However, we will only get this opportunity when we are willing to learn and work hard, earnestly and consistently in the long run. The vision and mission of the school can center, direct, motivate, and unite us in order to achieve the goals we want".

Strategic planning steps must be well planned. This was disclosed by Mr. MT as the Head of the School Principal Work Conference;

"...The relationship between the vision and mission of the school and the strategic planning that has been made by the school becomes a benchmark for getting high quality and superior students. Planning activities in schools cannot be avoided, so every school needs to plan in organizing school programs. if the school wants to achieve the best, then the school must use a strategic plan".

Mrs. SS as the Superintendent confirmed the statement of Mr. MT as the
Head of the School Principal Work Conference;

“...The focus of strategic planning includes planning in the field of curriculum, development of educational personnel, development and coaching in the field of student affairs, planning in finance, public relations and infrastructure. In improving the quality of education in schools it is more based on the ability of the principal as the main factor in preparing, running the program in addition to significant support from the teacher board, school administration staff, students and the community in the school environment".

Based on the statements of the three resource persons, it can be explained that strategic planning at Jetis Public Elementary Schools, creates and develops annual work programs according to the school's vision and mission, conducts external and internal audits, sets long-term goals, then formulates, evaluates, chooses strategic, and continues implementation. by measuring and evaluating school performance with planning in the field of curriculum, development of educational personnel, development and coaching in the field of student affairs, planning in finance, public relations and infrastructure.

\section{Implementation of School Quality Strategic Management}

The implementation of strategic management at the Jetis Public Elementary School begins with the preparation of a strategic plan. This was conveyed by Mrs. SW as the Principal of the School; 
"...We carry out several stages in managing the strategic plan by means of diagnosing, planning, developing and compiling documents in a systematic and structured manner".

The same was stated by Mr. MT as the Head of the Principal's Working Conference;

"...After the diagnosis process of collecting external and internal studies, then the school sets a vision and mission that describes the desired state of the school in the future by considering the formulation".

Observations made by researchers also show that the school agenda procedure document describes the methods and approaches used to achieve strategic goals. This step includes the identification of strategic options that can achieve objectives, evaluation of strategic alternatives using definite criteria and the selection of alternative groups that become strategic targets.

This is like what Ms. SW said by the Principal;

"...Strategic management is carried out in stages, first I fix the teacher, then the students, the next stage I fix the structure and the final stage of cleanliness which will be sustainable. So this school is classified as a favorite in Jetis because it has a large number of students, besides that the implementation of the school program goes well according to planning goals and support from various community parties in the school environment".

Mrs. SS as the Superintendent also expressed the same thing;

"...As I have said, the development stage is formulated based on the vision and mission carried out by the school quality development team (TPMS) in order to deal with the main issue (strategic issue). The sequence of strategic development is arranged according to the main issues. In strategic formulation, development can be differentiated according to the target group, with details consisting of three levels such as main strategic, sub-strategic, and strategic details".

The implementation of strategic planning related to the development of interests, talents and achievements is carried out in careful strategic design so that it is easy to understand. This was stated by Mr. SG as a grade 6 teacher;

"...The strategic plan document formulation stage is formulated briefly not too thick so that it is easy to understand and can be carried out by the TPMS team in a careful and flexible manner, the formulation can be carried out from the time of the study which has resulted in findings".

In line with Mr. SG, Mr. IS as the Committee confirms the previous statement that;

"...The best alternative plan is the alternative planning that is most likely to be implemented in schools, which has the most contribution to the movement of school development in related aspects and allows for changes when the implementation process requires adjustments to circumstances".

All of the implementation of strategic planning in improving the quality of education in Jetis Public Elementary Schools is to form 
school policies based on the vision, mission and goals of the school, motivate educators and education personnel, allocate human resources, and develop a strategic supportive culture. This data is supported by statements from several sources.

Mr. MT as the Head of the Principal's Working Conference stated that;

“...The strategic planning process has various forms of provisions, one of which is determining school policy by applying rules, rules, or values that must be carried out by the school. The policy can be in the form of rules that have been set by the government or the school it self".

The committee as one of the activators of the local school community members supported the previous resource persons' statements;

“...Strategic implementation is an action process that requires support from all staff and employees. The motivation process is needed so that employees fully support the strategy that will be and is being run by the school. Not only that, in creating an effective learning process, it is necessary to allocate human resources in accordance with their respective fields, this is done in order to improve student achievement".

The benefits of strategic planning for schools in improving the quality of education at Jetis Public Primary Schools are not only to broaden the knowledge of developing schools but also to improve school performance. The documentation of the results of the school's strategic planning in improving the quality of education with tutoring institutions shows significant things.

\section{Figure 1. Stage of the Strategic Plan for SD}

Negeri Jetis

Another benefit of school strategic planning is the increased public trust in sending their children to Jetis Public Elementary Schools. The source of documentation data that the researchers found also shows that the development of the vision and mission of implementing the strategic plan of the Jetis Public Elementary School based on the results in the field is very much in line with the previously formulated objectives, so that it has experienced an increasingly rapid development from year to year. 
Table 1. Key Success Factors for SD Negeri Jetis

\begin{tabular}{|c|c|}
\hline $\begin{array}{c}\text { Standard } 8 \\
\text { Components }\end{array}$ & Key Success Factors \\
\hline Content Standards & The existence of a complete and perfect operational curriculum. \\
\hline Process Standards & $\begin{array}{l}\text { Learning plans and implementation of teaching and learning activities } \\
\text { that are competency-based and refer to creativity and innovation. }\end{array}$ \\
\hline $\begin{array}{l}\text { Graduation } \\
\text { Competency Standards }\end{array}$ & $\begin{array}{l}\text { Students who have the knowledge, skills, attitudes and behaviors } \\
\text { (competencies) in accordance with Du/Di's needs. }\end{array}$ \\
\hline $\begin{array}{l}\text { Educators and } \\
\text { Education Personnel } \\
\text { Standards }\end{array}$ & $\begin{array}{l}\text { Availability of human resources for educators and educational personnel } \\
\text { who are professional, responsible and able to adapt to the development } \\
\text { of science and technology. }\end{array}$ \\
\hline $\begin{array}{l}\text { Standard Facilities and } \\
\text { Infrastructure }\end{array}$ & $\begin{array}{l}\text { Availability of facilities and infrastructure in accordance with the needs } \\
\text { of the learning program and unit development. }\end{array}$ \\
\hline Management Standards & $\begin{array}{l}\text { The existence of an orderly, neat and complete administration, supported } \\
\text { by a reliable management information system. }\end{array}$ \\
\hline Financing Standard & Availability of adequate financial support for management costs. \\
\hline Assessment Standards & Implementing an application-based (IT) assessment system. \\
\hline $\begin{array}{l}\text { Development of } \\
\text { School Environment } \\
\text { and Culture }\end{array}$ & $\begin{array}{l}\text { A conducive school environment is neatly arranged supported by a } \\
\text { school culture that emphasizes cleanliness, health and environmental } \\
\text { beauty. }\end{array}$ \\
\hline
\end{tabular}


Some of the opinions above can be concluded that the implementation of strategic management in Jetis Public Elementary Schools takes the stages, namely; diagnose, plan, develop and compile documents in a systematic and structured manner. The implementation of strategic planning in improving the quality of education forms school policies based on the vision, mission and goals of the school by implementing rules, rules, or values that must be carried out by schools, motivating educators and education personnel, allocating human resources, and developing a culture that supports strategic.

\section{Evaluation of School Quality Strategic Management}

Strategic management evaluation is carried out with the aim of finding out whether the implementation of strategic planning in improving school quality is in accordance with the plan. Said Mrs. SW as the Principal of the School that the purpose of evaluation is as the basis for whether a strategic planning will be continued, increased or stopped;

“...In every activity, evaluation must always be carried out so that unwanted things occur in an activity. The process is aimed at ascertaining whether the strategic actions taken by the school are in accordance with the strategic formulation that has been made and determined. By considering the strengths and weaknesses of each activity, this can become our basis for determining whether the activity is continued, increased, or not carried out longer".

Mr. MT as the Head of the Principal's Working Conference also explained the same thing;

"...This evaluation activity tries to test the basic assumptions or bases used in strategic formulation, whether they are still relevant or have changed considerably, whether the planning has been successful so that it continues or is stopped because it doesn't work".

Based on the evaluation of strategic planning activities, data was found about the supporting factors for the success of school strategic planning in improving the quality of education and the factors that hinder it and how to overcome these obstacles. The supporting factor of strategic planning in improving the quality of education in Jetis Public Elementary Schools is good support from all existing stakeholders, including students, teachers, supervisors, committees, and student guardians.

Mr. SG as a grade 6 teacher said;

"Alhamdulillah ... strategic planning in our school is supported by all parties, including students, teachers, and committees, including student guardians. Support from the committee and student guardians in the form of motivation and ideas poured out through socialization can 
work well together and be implemented in the school environment".

The inhibiting factor for school strategic planning in improving the quality of education at Jetis Public Elementary Schools is the inaccuracy in taking formulas.

Mrs. SW as the Principal of the School confirmed this statement;

"...The factor that hinders our strategic planning is the inaccuracies in the formulation. Accuracy is prioritized in taking the initial steps of change, so that actions that need to be taken are monitoring all results of planning and implementation, measuring individual and school performance, and taking corrective steps".

The problem of inaccurate formulation that hinders the implementation of the school's strategic plan can be through deliberations with the committee and the student guardians together to discuss the accuracy of policies in strategic planning.

Mrs. SW as the Principal of the School added the statement;

"Alhamdulillah ... because of the excellent support from the committee and the guardians of the students, every activity and implementation of the school's strategic planning development has experienced problems and has not been maximal in our school, after inviting the committee and the student guardians through socialization activities to sit together then solve the problem, the committee and student guardians are able to contribute to their ideas of a problem facing the school in order to open new avenues in the development of a sustainable strategic plan".

Based on some of the data above, it can be explained that the evaluation of strategic planning in improving the quality of education at Jetis Public Elementary Schools is carried out by analyzing the suitability of the strategic plan implementation, the results of the evaluation are used as a basis for determining whether a program is continued, improved, or stopped. In the evaluation, it is known that the supporting factors for the success of school strategic planning are very good support from students, teachers, committees, and student guardians, and from the evaluation also found inhibiting factors in school strategic planning, namely the problem of formulation inaccuracies, school cooperation with the committee and student guardians through deliberation can solve the inhibiting factors.

\section{DISCUSSION}

\section{School Quality Strategic Planning}

Based on the results in the field, it is known that strategic planning at the Jetis Public Elementary School is carried out by the school principal by forming a school quality development team (TPMS), after forming the school vision and mission formulation and formulation. A number of 
school visions, missions and goals that were successfully formulated were discussed in an annual school work meeting (RAKER) which involved all teachers, school heads, supervisors, committees, and student guardians to develop a school quality improvement program. From the results of the school's annual work meeting, a strategic plan (RESTRA) was born as a reference for making school work plans or programs, starting from long-term programs to daily work plan programs. In accordance with the theory that planning in improving the quality of educational institutions is a plan formulated by the principal together with a special team to achieve a goal (Sutina, 2011).

Planning is part of the management function. Planning according to Husaini Usman (2008) is a predetermined activity within a certain period of time in order to achieve goals, planning can be used to determine the goals to be achieved during the coming period and what must be done to achieve these goals.

The description of planning by Husaini Usman (2008) is in accordance with the findings of researchers at the research location. School strategic planning in improving the quality of education requires careful and directed planning. Strategic planning in improving the quality of education at SD Negeri Jetis, namely formulating the vision, mission and school objectives formulated at the beginning of the school year, conducting external and internal environmental studies, forming a school quality development team, making long-term annual work programs up to work plan programs daily then evaluate the results of development and coaching in the achievement of goals.

The existence of the school's vision and mission is very important. The vision and mission of the school is made by the teacher council who has a fighting spirit to move education practitioners to improve the quality of education by strategic planning and making strategic design programs in improving the quality of education. The work plan is made by the principal and all teachers, supervisors, committees, and student guardians as a guideline for implementing school performance. The work plan is made at the beginning of the school year through an annual work meeting based on an analysis of school needs that has been analyzed using SWOT. The work program made includes an annual work program, a semester work program, and a daily work program.

The focus of the strategic planning of the Jetis Public Elementary School consists of six parts, namely: planning in the field of curriculum, development of educational personnel, development and coaching of the student sector, planning in the financial sector, public relations and infrastructure. This is marked by the 
existence of various activities that involve all stakeholders, including programs to improve the quality of education through additional learning hours; improving the quality of teachers through upgrading, training, supervision and further education; student education through worship practices, scouts, leadership training; fostering interest in talents covering the fields of religion, science and technology, sports, arts; as well as programs to increase funding through the participation of committees, student guardians, communities, and agencies that support the financing of school quality improvement programs. In accordance with the theory presented by Mukhtarudin (2014) that the implementation of the education quality improvement program is carried out by empowering all existing components, with the aim of all programs in educational institutions to be well realized.

\section{Implementation of School Quality}

\section{Strategic Management}

The implementation of strategic management in improving the quality of education at Jetis Public Elementary Schools is an implementation of the planning stage by carrying out several stages, namely diagnosing, planning, developing and compiling documents in a systematic and structured manner. The implementation of strategic management is the key to success in order to achieve high quality education by means of; Determining policies based on the vision, mission and goals of the school, motivating educators and education personnel, allocating human resources, developing a school culture with values that are held firmly by school members, so that schools can produce high quality graduates in intellectual development and improve the quality of their education. The timing of school planning is adjusted to the educational agenda procedures made by the Office of Youth and Sports Education.

Regarding the implementation of school strategic planning in determining policies, the school establishes superior programs, makes rules for students, teachers, and implements a curriculum with a variation learning model, as formulated by Michael (1990) in implementing strategic planning consisting of mastery of cognitive aspects (abilities), affective aspects that are more comprehensive, and aspects of skills in the form of professional capacity.

The strategic planning model carried out by the Jetis State Elementary School according to Sulistyani (2017) is mutualism planning, namely planning for two or more parties who are equally aware of the important aspects of strategic planning, mutually beneficial and obtaining more benefits, so as to achieve goals. more optimally. 
Sallis (2012) states that quality is a philosophy and methodology that helps institutions plan change and set agendas in the face of excessive external pressures. Strategic planning is carried out at the Jetis Public Elementary School to implement policies, support and motivate educators and education personnel, allocate human resources effectively, and develop a school culture with values held firmly by school residents.

William's opinion in Marno and Supriyatno (2013) that quality improvement management or Total Quality Management is a set of principles and techniques that emphasize quality improvement based on educational institutions to continuously improve organizational capabilities to meet the needs of students and society. This can be seen in the strategic planning at the Jetis Public Elementary School which is able to add insight, knowledge of students and teachers about school development and open the school community's insight that schools will not be successful by themselves without collaboration with various parties and other institutions.

Wiliam in Marno and Supriyatno (2013) also said that improving quality is an action taken by educational practitioners to increase the value of products for clients through quality improvements. A good quality school is one that is able to produce students who have ordinary abilities to become something special. SD Negeri Jetis is able to improve school performance after implementing strategic planning, the principal makes appropriate policies in collaboration with various parties and other institutions in implementing strategic planning. the provision of professional staff to support teachers in facing graduation exams and competitions, the result is that schools are able to win competitions at the sub-district, district, provincial and national levels. School graduates for the last 3 years have always been champions in each of their school districts.

Sallis (2012) states that quality quality is related to client satisfaction. This is consistent with the findings of researchers at Jetis Public Elementary Schools that school strategic planning is able to increase public trust. Improve school performance and be accompanied by increased public trust in sending their children to school. It is proven by the number of students in the last 3 years always increasing.

\section{Evaluation of School Quality Strategic Management}

Terry (2012) states that evaluation is an activity to adjust between implementation and predetermined plans. Evaluation in the implementation of the strategic planning of the Jetis Public Elementary School was carried out to analyze the suitability of the school's strategic design implementation with 
planning. The results of the evaluation are used as the basis for determining whether a program planning will be continued, improved, or stopped.

Evaluation of strategic planning management at SD Negeri Jetis was conducted to find supporting factors and obstacles to planning. The supporting factor for the success of strategic planning is the active participation of students, teachers, supervisors, committees, student guardians, and the community in the school environment. The principle of strategic planning is classified as mutualism according to Sulistyani (2017), this is carried out between school principals, teachers, supervisors, heads of school principal work deliberations, committees, student guardians and the school environment community. The problem faced by schools in strategic planning is the problem of inaccuracies in taking formulas. The school tries to find a way out by way of deliberation with the committee and student guardians. The formulation inaccuracies in strategic planning was met by the committee and the student guardians. The committee and student guardians realize that the success of their children's education is not only the responsibility of the school, but must be a shared responsibility.

\section{CONCLUSION}

The conclusion from writing this article is that (1) strategic planning in the
Jetis Public Elementary School makes an annual work plan in accordance with the vision, mission and goals of the school which is formulated at the beginning of the school year in the long term, forms a school quality development team, determines the timing of school planning accordingly educational procedures, evaluating the results of development and coaching in the achievement of goals. (2) implementation of school strategic management planning to diagnose, plan, develop and compile documents in a systematic and structured manner. determine policies, motivate educators and education personnel, allocate human resources, and develop a strategic supportive culture. Strategic planning is a mutualism design, the benefits of school strategic planning are to improve school performance so that public trust in schools increases. (3) evaluation of the school's strategic management by analyzing the suitability of the strategic design implementation with planning. the results of the evaluation are used as a basis for determining whether a program will be continued, improved, or stopped. knowing the supporting factors for the success of strategic planning, namely the active participation of students, teachers, supervisors, committees, guardians of students, and the community in the school environment, as well as finding the inhibition of school strategic planning 
factors, namely the problem of formulation inaccuracies, the school collaborates with the committee and student guardians to solve the inhibiting factors said.

\section{Acknowledgments}

Researchers would like to thank the Principal, Teachers, Guardians and Students of SD Negeri Jetis Bantul, all educational resource experts, especially Mrs. Dra. Sri Sudarmi, M.Pd as the School Superintendent, Mr. Martono, M.Pd as the Head of the School Principal Work Conference, and Mr. Imam Syamroni, M.Sc as the School Committee, as well as all parties that I cannot mention one by one, so that it can work well.

\section{REFERENCES}

Amirin, T.M. (2005). Strategic Planning Models. Journal of Educational Management, 1 (1): 31-35.

Anthony, Robert $\mathrm{N}$ and Govindarajan V. (2007). Management Control Systems. International Edition. McGraw-Hill: New York-USA.

Apple, Michael. W. (1990). Ideology and Curriculum. Edition 2. Routledge: New York-London.

Arcaro, Jerome S. (1995). Quality in Education: An Implementation Handbook. Edition 1. Routledge Florida: St. Lucie Press.

Arrowsmith. (1985). Public Procurement: An Appraisal of the UNCITRAL Model Law as a Global Standard. International Law \& COMP Quarterly. http://dx.doi.org. Accessed December 10, 2020.

Boseman, G and A. Phatak. (1989). Strategic Management, Text and Cases. Edition 2. John Wiley and Sons Incorporated: New York-USA.

Danim. (2006). Leadership Motivation and Group Effectiveness. Edition 2. Jakarta: PT Rineka Cipta.

Ministry of National Education. (2002). School Based Quality Improvement Management. Book I. Jakarta: Depdiknas.

Djunaedi, Achmad. (2000). A variety of planning styles to support regional autonomy policies. in Seminar \& MPKD. 27-30 August 2000. Werdhapura, Sanur, Bali. Thing. 4.

Edward, Sallis. (2012). Total Quality Management in Education: Education Quality Management. Edition 6. Yogyakarta: IRCiSoD. Thing. 226.

Fattah, Nanang. (2004). Educational Management Foundation. Edition 5. Bandung: PT Remaja Rosdakarya.

Godwin, R. (2017). Low Quality of Education in Indonesia. Psychology Binus University. Retrieved from https://psychology.binus.ac.id/2017/02 $\angle 17 /$ low-quality-educationeducation-inindonesia. Retrieved 26 November 2020. Hefniy and Fairus, R.N. (2019). Strategic Management in Improving the Quality of Personnel Services. Al-Tanæim Journal of 
Islamic Education Management. 3 (1): 169197.

Hoy, K Wayne, and Miskel, Cecil G. (2001).

Educational Administration: Theory, Research, and Practice. Edition 9. McGraw-Hill: New York-USA.

Huberman, A. Michael and Miles, M. (1992).

Qualitative Data Analysis. Latest edition. Jakarta: UII Press.

Husaini Usman. (2008). Management Practice

Theory, and Educational Research. Edition 2. Jakarta: Earth Literacy.

The Ministry of National Education. (2005).

Directorate General of Primary and Secondary Education. Directorate of Secondary and Vocational Schools. The Ministry of National Education.

Kerzner, H. (2001). Project Management: $A$ Systems Approach to Planning, Scheduling and Controlling. Issue 7. John Wiley and Sons Incorporated: New York-USA.

Komariah. (2005). Visionary Leadership Towards Effective Schools. Jakarta: Earth Literacy. http://www.damandiri.or.id Accessed December 10, 2020.

Kurniawati, E (2017). Strategic Management of Islamic Education Institutions in Improving the Quality of Education. AtTaqaddum Journal. 9 (1): 125-131.

Lubis, Mayang S. (2008). Educational Strategy Planning. Asian Journal Of Islamic Management. 2 (2): 45-59.
Marno \& Supriyatno, T. (2013). Islamic Education Leadership Management. Edition 2. Bandung: PT Refika Aditama.

Mintzberg, H. (1994). The Fall and Rise Of Strategic Planning. Hardvard Business Review. School Publishing JanuaryFebruary 1994. Boston, MA. U.S-Canada. Thing. 108-114.

Mukhtaruddin. (2014). Human Resource Development in Improving Employee Performance at STAINT Dirundeng. Journal of AT-TA'DIB. 2 (3): 102.

Murdick, R.G. (1985). Information Systems for Modern Management. Edition 3. PrenticeHall Private Limited: New Delhi-India.

Nawawi, Hadari. (2005). Strategic Management of Non-Pofit Organizations in Government Sector with Illustrations in the Education Sector. Edition 5. Yogyakarta: Gajah Mada University Press.

Prasojo, L.D. (2011). Vocational High School Development Model with Strategic Planning Approach. Journal of Educational Management. 7 (1): 84-91.

R. Terry, George \& W. Rue, L. (2012). Fundamentals of management. Edition 13. Jakarta: Earth Literacy.

Rusmini. (2017). Improving the Quality of Human Resources through Character and Attitude Education. Journal of Nur-El Islam. 4 (2): 91-95.

Sallis, E. (2012). Total Quality Management. Text, Abmad Ali Riyadi. Edition 16. Yogyakarta: Ircisot. 
Satori, Djam'an and Komariah, A. (2010). Qualitative Research Methodology. Latest edition. Bandung: Alfabeta.

Sudradjad, Hari. (2005). School-Based Quality Improvement Management: Improving the Quality of Education through Implementation of CBC. Edition 1 Published. Bandung: Cipta Lekas Garafika.

Sugiyono. (2016). Combination Research Methods. Latest edition. Bandung: Alfabeta.

Sulistyani. (2017). Partnership and Empowerment Model. Edition 2. Jakarta: Gava Media.

Suryana, S. (2011). Education Quality Problems in the Perspective of Educational Development. Educational Journal. 1 (3): 2-12.

Sutikno, T.A. (2013). Vocational Education Strategic Management in Facing Quality Competition. Technology and Vocational Journal. 6 (1): 92-93.

Sutina, N. (2011). Education Quality Improvement Planning Guide. Edition 2. Bandung: Alfabeta.

Triton, PB. (2010). Human Resource Management. Latest edition. East Kalimantan: ORYZA.

1945 Constitution of the Republic of Indonesia, Preamble.

Law No. 20 of 2003 concerning the National Education System. Jakarta.
United Nations Development Program. (2020). Human Development Index. Indonesia.

Usman, Uzer. (2006). Become a Professional Teacher. Edition 2. Bandung: Youth Rosdakarya. 